\title{
Analisis Kesulitan Komunikasi Matematis Siswa Dalam Penerapan Model Pembelajaran Think Pair Share
}

\author{
Maryetta Evi Hariati ${ }^{1}$, Bornok Sinaga ${ }^{2}$, Mukhtar $^{3}$ \\ 1) 2) 3) Prodi Pendidikan Matematika Pascasarjana, Universitas Negeri Medan \\ ${ }^{1}$ Universitas Negeri Medan, Jalan William Iskandar Pasar V, Medan, Indonesia \\ mevihp@gmail.com
}

\begin{abstract}
This study aims to describe: (1) students' mathematical communication skills in the application of the Think Pair Share cooperative learning model; and (2) the difficulty of mathematical communication and students' creative thinking in solving mathematical problems through the Think Pair Share cooperative learning model. This research is qualitative research with a descriptive approach. The subjects in this study involved 35 students of grade VII-1 SMP Wiraswasta Batangkuis for the academic year 2020/2021. Based on the research data, it was found that: (1) The level of students' mathematical communication skills on the material of rectangles and squares in medium-ability students had the highest proportion, followed by low and high-ability students; and (2) The difficulty of students' mathematical communication skills in applying the Think Pair Share learning model is the difficulty of facts, concepts, operations, and principles.
\end{abstract}

Keywords: Mathematical Communication Skills, Think Pair Share, difficulty analysis

\begin{abstract}
Abstrak
Penelitian ini bertujuan untuk menganailisis: (1) Kemampuan komunikasi matematis siswa dalam penerapan model pembelajaran kooperatif Think Pair Share; dan (2) Kesulitan komunikasi matematis dan berpikir kreatif siswa dalam menyelesaikan masalah matematika melalui model pembelajaran kooperatif Think Pair Share. Penelitian ini merupakan penelitian kualitatif dengan pendekatan deskriptif. Subjek dalam penelitian ini melibatkan siswa kelas VII-1 SMP Wiraswasta Batangkuis tahun ajaran 2020/2021 yang berjumlah 35 orang. Berdasarkan data hasil penelitian diperoleh bahwa: (1) Tingkat kemampuan komunikasi matematis siswa pada materi pesegi panjang dan persegi pada siswa berkemampuan sedang memiliki proporsi tertinggi kemudian diikuti oleh siswa berkemampuan rendah dan tinggi; dan (2) Kesulitan kemampuan komunikasi matematis siswa dalam penerapan model pembelajaran Think Pair Share adalah kesulitan fakta, konsep, operasi, dan prinsip.
\end{abstract}

Kata kunci: Kemampuan Komunikasi Matematis, Think Pair Share, analisis kesulitan

Copyright (c) 2022 Maryetta Evi Hariati, Bornok Sinaga, Mukhtar

$\triangle$ Corresponding author: Maryetta Evi Hariati

Email Address: mevihp@gmail.com (Jalan William Iskandar Pasar V, Medan, Indonesia)

Received 23 December 2021, Accepted 05 February 2022, Published 06 February 2022

\section{PENDAHULUAN}

Kemampuan komunikasi matematis siswa dapat mengorganisasi dan mengkonsolidasi berpikir matematisnya baik secara lisan maupun tulisan, disamping renegoisasi respon antar siswa akan dapat terjadi dalam proses pembelajaran. Pada akhirnya komunikasi matematis dapat membawa siswa pada pemahaman yang mendalam tentang konsep matematika yang telah dipelajari (Ikhsan \& Rizal, 2014). Kemampuan berkomunikasi siswa dalam pembelajaran matematika perlu menjadi fokus $\mathrm{p}$ erhatian. Hal ini dikarenakan melalui komunikasi matematis siswa dapat mengeksplorasi ide-ide matematikanya. Oleh karena itu, siswa perlu dibiasakan memberikan argumen terhadap setiap jawabannya serta memberikan tanggapan atas jawaban yang diberikan orang lain, sehingga apa yang sedang dipelajari menjadi bermakna baginya.

Kemampuan komunikasi matematis merupakan kemampuan yang penting dalam kegiatan pembelajaran matematika. Kemampuan komunikasi matematis merupakan kemampuan yang selalu 
digunakan dalam menyelesaikan permasalahan matematika, mulai dengan menuliskan soal cerita menjadi bentuk simbol-simbol atau gambar. Sejalan dengan penelitian yang sudah dilaksanakan oleh Septiani (Septiani et al., 2013) yang menyatakan bahwa kemampuan komunikasi matematis memiliki peran yang sangat penting dalam pembelajaran matematika. Kemampuan komunikasi matematis juga memuat kemampuan dalam menuliskan penyelesaian secara sistematis dan urut.

Dalam belajar matematika (Soedjadi, 2011) mengatakan penyelesaian soal matematis dituntut untuk mampu membaca konsep-konsep,operasi hitung matematika dengan simbol-simbol, selanjutnya memahami makna yang terkadung dalamsimbol itu ke dalam satu konsep yang utuh, dan menyusun konsep itu ke dalambahasa sendiri sesuai dengan tingkat perkembangan intelektualnya. Hal ini sesuai dengan penelitian yang dilakukan oleh (Darkasyi et al., 2014) memperlihatkan bahwa "Rendahnya komunikasi matematis di Sekolah Menengah Pertama (SMP) disebabkan guru masih cenderung aktif dengan pendekatan ceramah menyampaikan materi kepada peserta didik sehingga siswa dalam mengkomunikasi matematis masih sangat kurang".

Melalui komunikasi matematis siswa dapat mengorganisasi dan mengkonsolidasi berpikir matematisnya baik secara lisan maupun tulisan, disamping renegoisasi respon antar siswa akan dapat terjadi dalam proses pembelajaran. Pada akhirnya komunikasi matematis dapat membawa siswa pada pemahaman yang mendalam tentang konsep matematika yang telah dipelajari (Ikhsan \& Rizal, 2014).

Dengan kemampuan komunikasi yang baik maka suatu masalah akan lebih cepat bisa direpresentasikan dengan benar dan hal ini akan mendukung untuk penyelesaian masalah. Menurut (Ikhsan \& Rizal, 2014) siswa yang tidak mampu memahami ide matematis akan sulit juga dalam mengkomunikasikan ide tersebut dalam tulisan maupun lisan sehingga siswa tidak mampu mengerjakan soal dan berdampak pada rendahnya prestasi siswa. Menyadari hal tersebut, dapat dikatakan bahwa komunikasi matematis sangat diperlukan dalam proses keberhasilan pembelajaran matematika.

Kemampuan komunikasi matematis rendah akibat dari respons siswa terhadap soal-soal komunikasi matematis umumnya kurang. Selain itu juga, disebabkan karena guru terlalu banyak menerangkan, sehingga suasana di dalam kelas menjadi tegang. Oleh karena itu, penting bagi guru untuk mengetahui kemampuan komunikasi matematis peserta didik dalam suatu pembelajaran matematika. Dengan mengetahui kemampuan komunikasi matematis peserta didik, guru dapat melacak dan menyelidiki seberapa jauh pemahaman matematis dan letak kesulitas dalam pembelajaran matematis, dimana terkait dengan indicator kesulitan siswa tidak paham dengan fakta, konsep, prinsip dan operasi dalam menyelesaikan soal, sehingga perlunya menganalisis terkait permaslahan matematis yang ada supaya siswa lebih memahami soal jika diberikan dalam bentuk permaslahan dalam bentuk soal cerita.

Hal ini dapat dilihat berdasarkan tes diagnostik yang diberikan penelitikepada siswa kelas VII-1 SMP Negeri 1 Galang. Tes diagnostik ini dilakukan peneliti dengan memberikan soal kepada 35 siswa. Soal ini dirancang agar penyelesaiannya dapat menunjukkan indikator komunikasi matematis 
yaitu menyatakan mengungkapkan ide atau situasi matematika dari suatu gambar yang dilengkapi dengan kata-katanya sendiri, menyatakan situasi dalam bentuk gambar atau grafik, menyatakan atau menjelaskan situasi dalam bentuk notasi atau symbolmatematika atau model matematika. Diperoleh hasil bahwa 18 siswa (47,37 \%) tergolong dalam kategori sangat rendah , 8 siswa (21,05\%) tergolong dalam kategori rendah hingga sedang, 7 siswa $(18,42 \%)$ tergolong dalam kategori sedang hingga cukup, 5 siswa $(13,16)$ tergolong dalam kategori cukup hingga baik.

Selanjutnya Ditjen GTK Kemdikbud (Ditjen GTK Kemdikbud, 2016) menjelaskan bahwa "hal-hal yang perlu dikembangkan dalam pembelajaran matematika adalah 1) penguasaan konsep matematika; 2) kemampuan memecahkan masalah; 3) kemampuan bernalar dan berkomunikasi; 4) kemampuan berpikir kreatif dan inovatif". Senada dengan Framework for Action (Framework for Action, 2016) tertulis bahwa ".... Education 2030 will ensure thatall individuals acquire a solid foundation of knowledge, develop creative and critical thinking and collaborative skill and build curiosity, courage, resilience" yang artinya pendidikan 2030 akan memastikan bahwa semua individu mendapatkan dasar yang kuat dari pengetahuan, mengembangkan pemikiran kreatifdan kritis dan keterampilan kolaboratif dan membangun rasa ingin tahu, keberanian, ketahanan.

Dengan menggunakan model pembelajaran yang inovatif, diharapkan siswa dapat memahami konsep dari materi pelajaran. Dengan konsep itu, hasil pembelajaran diharapkan lebih bermakna bagi siswa. Dengan begitu proses pembelajaran berlangsung alamiah dalam bentuk kegiatan siswa bekerja dan mengalami, bukan mentransfer pengetahuan dari guru ke siswa. Salah satu model pembelajaran yang diharapkan dapat menjadi pembelajaran yang bermakna bagi siswa adalah pembelajaran kooperatif.

Model pembelajaran kooperatif memiliki konsep belajar berkelompok yang mampu membuat siswa aktif dan kritis dalam pembelajaran karena dengan belajar berkelompok siswa akan bertanya mengenai materi pelajaran yang tidak diketahui kepada temannya tanpa rasa malu. Pembelajaran kooperatif dikenal dengan pembelajaran secara berkelompok. Tetapi belajar kooperatif lebih dari sekedar belajar kelompok atau kerja kelompok karena dalam belajar kooperatif ada struktur dorongan atau tugas yang bersifat kooperatif sehingga memungkinkan terjadinya interaksi secara terbuka dan hubungan yang bersifat interdepedensi efektif diantara anggota kelompok.

Shoimin (Shoimin, 2016) menyatakan bahwa "Think Pair Share adalah suatu model pembelajaran kooperatif yang memberi siswa waktu untuk berpikir dan merespon serta saling bantu satu sama lain". Terdapat ide waktu berpikir atau waktu tunggu dalam model ini yang menjadi faktor kuat dalam meningkatkan kemampuan siswa dalam merespons pertanyaan. Pembelajaran kooperatif model Think Pair Share ini relatif lebih sederhana karena tidak menyita waktu yang lama untuk mengatur tempat duduk ataupun mengelompokkan siswa. Model pembelajaran ini melatih siswa untuk berani berpendapat dan menghargai pendapat teman. Strategi Think Pair Share (TPS) atau berpikir berpasangan berbagi merupakan jenis pembelajaran kooperatif yang dirancang untuk memengaruhi polainteraksi siswa. 
Dengan menerapkan model pembelajaran kooperatif Think Pair Share dapat membangkitkan keterkaitan siswa terhadap materi matematika dan membuat siswa lebih aktif, mendorong kerja sama antar siswa dalam mempelajari suatu materi, sehingga dapat meningkatkan kemampuan komunikasi matematis dan berpikir kreatif siswa (Zulfah, 2017). Adapun kelebihan dari model pembelajaran ini Memungkinkan siswa untuk merumuskan dan mengajukan pertanyaan-pertanyaan mengenai materi yang diajarkan karena secara tidak langsung memperoleh contoh pertanyaan yang diajukan oleh guru, serta memperoleh kesempatan untuk memikirkan materi yang diajarkan. Sehingga proses pemebelajaran lebih aktif dan siswa akan lebih mudah mengembangkan dan meningkatkan kemampuan komunikasi matematis siswa.

Berdasarkan latar belakang yang diuraikan diatas, peneliti ingin melihat lebih mendalam mengenai permasalahan di atas dengan cara menganalisis kesulitan dari kemampuan komunikasi matematis siswa sehingga perlunya dilakukan penelitian ini. Berdasarkan hal tersebut peneliti bermaksud mengadakan penelitian berjudul: "Analisis Kesulitan Komunikasi Matematis Siswa Dalam Penerapan Model Pembelajaran Think Pair Share".

\section{METODE}

\section{Jenis Penelitian}

Penelitian ini menggunakan penelitian kualitatif. Jenis penelitian kualitatif artinya suatu jenis penelitian yang bertujuan untuk mendeskripsikan bagaimana kemampuan komunikasi matematis dan berpikir kreatif siswa dalam penerapan model pembelajaran Think Pair Share di kelas VII SMP Wiraswasta Batangkuis. Data yang dihasilkan nantinya berupa kata-kata atau ucapan-ucapan yang diperoleh dari hasil wawancara dan tulisan atau bilangan yang diperoleh dari hasil wawancara. Berdasarkan pendekatan kualitatif dalam penelitian ini, semua fakta baik tulisan maupun lisan dari sumber data manusia yang telah diamati dan dokumen terkait lainnya yang diuraikan apa adanya kemudian dikaji seringkas mungkin untuk menjawab permasalahan. Penelitian ini dilaksanakan di SMP Wiraswasta Batangkuis kelas VII Pada Tahun Ajaran 2020/2021, pada semester dua (genap) dengan jadwal pelaksanaannya dikoordinasikan dengan kegiatan sekolah. Subjek dalam penelitian ini melibatkan siswa kelas VII-1 SMP Wiraswasta Batangkuis, yang diberi perlakuan melalui model pembelajaran Think Pair Share pada semester genap tahun ajaran 2020/2021 yang berjumlah 35 orang. Sedangkanmateri pelajaran yang diberikan adalah segi empat.

\section{Teknik Pengumpulan Data}

Proses pengumpulan data ini meliputi proses memasuki lokasi penelitian sertaberada di lokasi penelitian dan mengumpulkan data penelitian. Metode pengumpulan data yang diperlukan dalam penelitian ini adalah tes komunikasi matematis, wawancara kepada siswa dan guru, dan dokumentasi berupa foto, vidio selama proses pembelajaran berlangsung serta menganalisis dilapangan menggunakan model Miles dan Huberman, yaitu data reduction, data display, dan data conclusion drawing/verification. 


\section{Analisis Data}

Analisis data dalam penelitian ini menggunakan analisis data kualitatif dimana analisis data dilakukan setelah pemberian suatu tindakan pembelajaran. Menurut Bogdan (Trianto., 2011) mengemukakan bahwa analisis data kualitatif adalah proses-proses mencari serta menyusun secara sistematis data yang diperoleh dari hasil wawancara, catatan lapangan, dan bahan-bahan lainnya sehingga mudah dipahami agar dapat diinformasikan kepada orang lain. . Analisis data tersebut dilakukan dengan mengorganisasikan data, menjabarkannya ke dalam unit-unit, melakukan sintesis, menyusun ke dalam pola, memilih mana yang penting, dan yang akan dikaji sehingga dapat dibuat suatu kesimpulan untuk disampaikan kepada orang lain. Aktivitas dalam analisis data menggunakan model Miles dan Huberman, yaitu data reduction, data display, dan data conclusion drawing/verification.

\section{HASIL DAN DISKUSI}

Data yang akan dipaparkan dalam penelitian ini yaitu kemampuan komunikasi matematis dan gambaran wawancara peneliti dengan siswa. Kemudian dari data yang ada dilakukan triangulasi data untuk menganalisis kesulitan siswa dalam pemecahan masalah komunikasi matematis dalam menyelesaikan masalah matematika melalui model pembelajaran Think Pair Share. Melalui analisis data tersebut dapat dilakukan penarikan kesimpulan berupa temuan baru. Penarikan kesimpulan yaitu mendeskripsikan komunikasi matematis dan berpikir kreatif siswa setelah diterapkannya model pembelajaran Think Pair Share serta kesulitan siswa dalam menyelesaikan masalah matematika terkait dengan komunikasi matematis.

\section{Deskripsi Data Kemampuan Komunikasi Matematis Siswa DalamPenerapan Model Pembelajaran Think Pair Share}

Penskoran tes kemampuan komunikasi siswa diberikan berdasarkan pedoman penskoran yang telah disusun, maka diperoleh kemampuan komunikasi siswa setelah diterapkannya model pembelajaran Think Pair Share pada tabel 1 berikut.

Tabel 1. Hasil Tes Kemampuan Komunikasi Siswa Setelah DiterapkannyaModel Pembelajaran Think Pair Share

\begin{tabular}{|c|c|c|c|c|}
\hline No & Interval SKKM & Jumlah Siswa & Persentase & Tingkat \\
\hline 1 & $0 \leq$ SKKM $<65$ & 7 & $28 \%$ & Rendah \\
\hline 2 & $65 \leq$ SKKM $<80$ & 14 & $56 \%$ & Sedang \\
\hline 3 & $80 \leq$ SKKM $<100$ & 4 & $16 \%$ & Tinggi \\
\hline
\end{tabular}

Catatan : SKKM = Skor Kemampuan Komunikasi Matematis (Purba, 2017)

Tabel 1 di atas menunjukkan bahwa dari 25 siswa yang mengikuti tes, siswa dengan tingkat kemampuan komunikasi matematis rendah sebanyak 7 siswa(28\%), siswa yang memiliki tingkat kemampuan komunikasi matematis sedang sebanyak 14 siswa (56\%) dan siswa yang memiliki tingkat kemampuan komunikasi matematis tinggi sebanyak 4 siswa (16\%). Karena masih banyak siswa yang memilikitingkat kemampuan komunikasi rendah dan sedang, ini menunjukkan 
bahwa masihbanyak siswa yang melakukan kesalahan dalam memecahkan persoalan komunikasi matematis yang diberikan. Maka perlu ditelusuri kesulitan-kesulitan yang dialami oleh siswa yang melakukan kesalahan dalam memecahkan masalah komunikasi matematis.

Terlihat bahwa masih banyak siswa yang memiliki kemampuan komunikasi matematis dengan kategori sedang dan rendah. Mulqiyono menjelaskan bahwa rendahnya kemampuan komunikasi matematik siswa diakibatkan oleh kecenderungan siswa yang menganggap mata pelajaran matematika sebagai matapelajaran ynag sulit. Anggapan siswa tehadap matematika merupakan matapelajaran yang sulit akan berimbas pada motivasi belajar siswa yang rendah dan kemampuan komunikasi matematik siswa karena kurangnya keikutsertaan siswa dalam kegiatan pembelajaran. Selanjutnya redahnya kategori tinggi pada kemampuan matematika siswa juga disebabkan karena siswa masih mengalami kesulitan mengartikan simbol-simbol dalam bangun datar, membaca simbol dan mengomunikasikannya secara lisan maupun tulisan. Hal tersebut terjadi baik pada siswa dengan prestasi tinggi, prestasi sedang maupun prestasi rendah. Hasil kemampuan komunikasi siswa tersebut juga dapat dilihat pada diagram berikut.

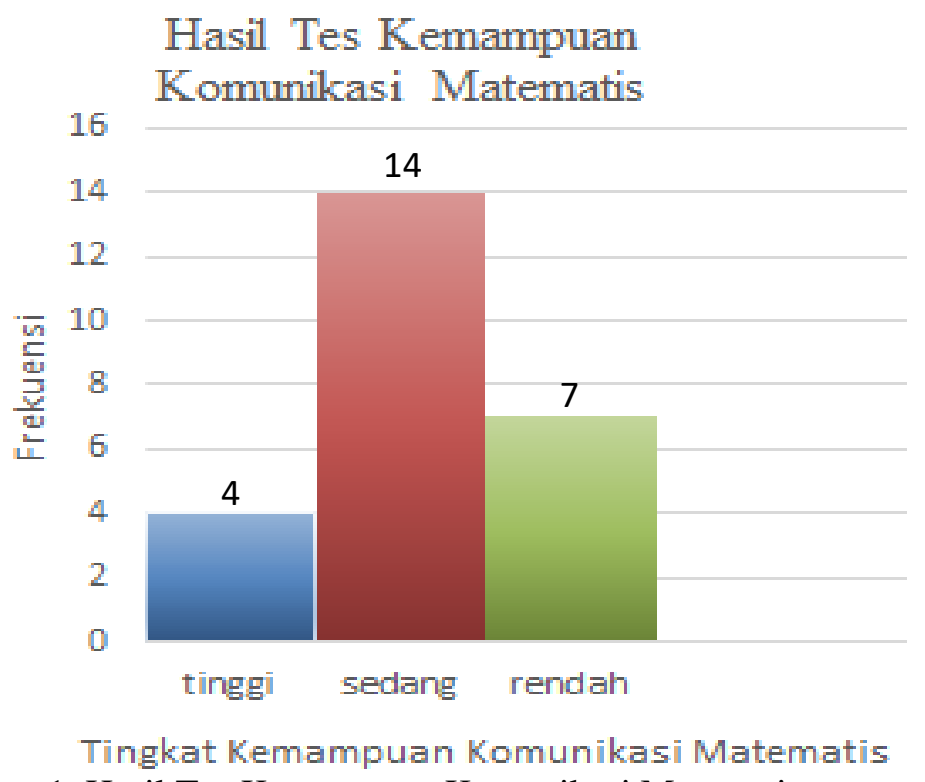

Gambar 1. Hasil Tes Kemampuan Komunikasi Matematis

\section{Analisis Data Kesulitan Komunikasi Matematis Siswa Dalam Menyelesaikan Masalah Matematika Melalui Model Pembelajaran Think Pair Share}

Setelah dilakukan penilaian sesuai dengan alternatif jawaban yang telah disusun, S-1 memperoleh nilai sebesar 16,67 atau tergolong pada tingkat kemampuan komunikasi matematis dengan kategori rendah. Hasil jawaban S-1 untuk tes nomor soal pertama dapat dilihat pada gambar berikut. 


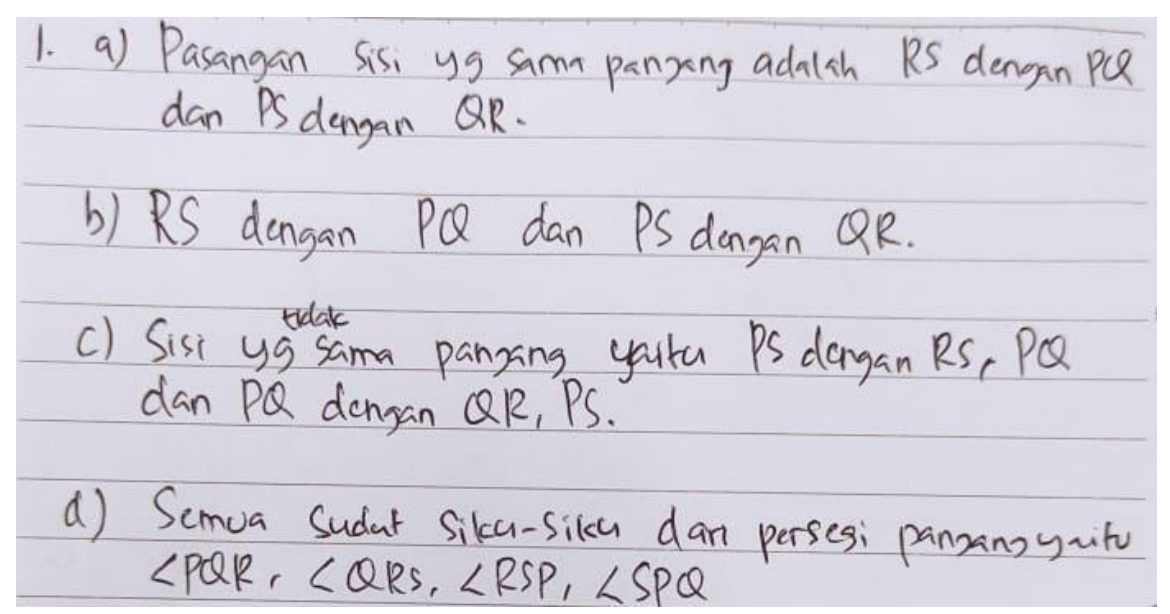

Gambar 2. Hasil jawaban S-1 untuk Soal Nomor 1

Berdasarkan gambar diatas di atas terlihat bahwa S-1 dapat menjawab 4 dari 6 permasalahan pada soal nomor 1, pada soal no 1 tersebut S-1 dapat menyebutkan pasangan sisi yang sama panjang, pasangan yang sejajar, sisi yang tidak sama panjang dan semua sudut siku-siku dari persegi panjang tersebut. Setelah dipaparkan hasil tes dan dilakukan analisa data, maka diperoleh temuan dalam penelitian ini yaitu dari 25 siswa yang mengikuti tes, siswa dengan tingkat kemampuan komunikasi matematis rendah sebanyak 7 siswa (28\%), siswa yang memiliki tingkat kemampuan komunikasi matematis sedang sebanyak 14 siswa (56\%) dan siswa yang memiliki tingkat kemampuan komunikasi matematis tinggi sebanyak 4 siswa (16\%).

Temuan selanjutnya yaitu dari 25 siswa yang mengikuti tes, siswa dengan tingkat kemampuan berpikir kreatif rendah sebanyak 19 siswa (76\%), siswa yang memiliki tingkat kemampuan berpikir kreatif sedang sebanyak 6 siswa (24\%) dan tidak ada siswa yang memiliki kemampuan berpikir kreatif dalam kategori tinggi. Temuan selanjutnya yaitu, dari 6 subjek penelitian untuk kemampuan komunikasi matematis, S-1 memiliki kesulitan pada tingkat fakta, konsep, operasi dan prinsip. S-2 memiliki masalah kesulitan bagian, konsep, dan prinsip.S-3 mengalami kesulitan fakta, prinsip dan operasi, S-4 mengalami kesulitan fakta, S-5 mengalami kesulitan konsep dan fakta, serta S-6 mengalami kesulitan pada tingkat operasi.

\section{KESIMPULAN}

Tingkat kemampuan komunikasi matematis siswa pada materi pesegi panjang dan persegi pada siswa berkemampuan sedang memiliki proporsi tertinggi kemudian diikuti oleh siswa berkemampuan rendah dan tinggi. Dari 6 subjek penelitian untuk kemampuan komunikasi matematis, S-1 memiliki kesulitan pada tingkat fakta, konsep, operasi dan prinsip. S-2 memiliki masalah kesulitan bagian, konsep, dan prinsip.S-3 mengalami kesulitan fakta, prinsip dan operasi, S-4 mengalami kesulitan fakta, S-5 mengalami kesulitan konsep dan fakta, serta S-6 mengalami kesulitan pada tingkat operasi. 


\section{UCAPAN TERIMA KASIH}

Terima kasih saya ucapkan kepada dosen pembimbing Bapak Prof. Dr. Bornok Sinaga, M.Pd., dan Bapak Dr. Hermawan Syahputra, M.Si. Terima kasih juga saya ucapkan untuk semua pihak yang membantu dalam menyelesaikan penelitian ini.

\section{REFERENSI}

Darkasyi, M., Johar, R., \& Ahmad, A. (2014). Peningkatan Kemampuan Komunikasi Matematis dan Motivasi Siswa dengan Pembelajaran Pendekatan Quantum Learning pada Siswa SMP Negeri 5 Lhokseumawe. Jurnal Didaktik Matematika, 1(1), 21-34. https://doi.org/10.24815/dm.v1i1.1336 Ditjen GTK Kemdikbud. (2016). Guru Pembelajaran, Modul Matematika SMP. Kelompok Kompetensi.

Framework for Action. (2016). Education 2030 Incheon Declaration and Framework for Action. Unesco. 2016.

Ikhsan, M., \& Rizal, S. (2014). Meningkatkan Kemampuan Pemahaman Dan Komunikasi Matematis Siswa Sekolah Menengah Atas Melalui Model Pembelajaran Generatif. Didaktik Matematika, 1(2), 75-84. https://doi.org/10.24815/jdm.v1i2.2070

Purba, E. P. (2017). Analysis of the Difficulties of the Mathematical Creative Thinking Process in the Application of Problem Based Learning Model. AISTEEL 2017. Advances in Social Science, Education and Humanities Research, 104, 265-268.

Septiani, M. D., Sukestiyarno, \& Suyitno, A. (2013). Pembentukan Karakter dan Komunikasi Matematika Melalui Model Problem Posing Berbantuan Scaffolding Materi Segitiga. Kreano, Jurnal Matematika $\quad$ Kreatif-Inovatif, $\quad 4(1), \quad 41-49$. https://doi.org/10.15294/kreano.v4i1.2891.g2965

Shoimin, A. (2016). 68 Model Pembelajaran Inovatif dalam Kurikulum 2013. Ar-Ruzz Media. Soedjadi. (2011). Kiat Pendidikan Mateatika di Indonesia. Dirjen Dikti.

Trianto. (2011). Mendesain Model Pembelajaran Inovatif - Progresif. Prestasi Pustaka.

Zulfah. (2017). Pengaruh Penerapan Model Pembelajaran Kooperatif Tipe Think Pair Share (Tps ) Terhadap. 01(2), 1-12. 